
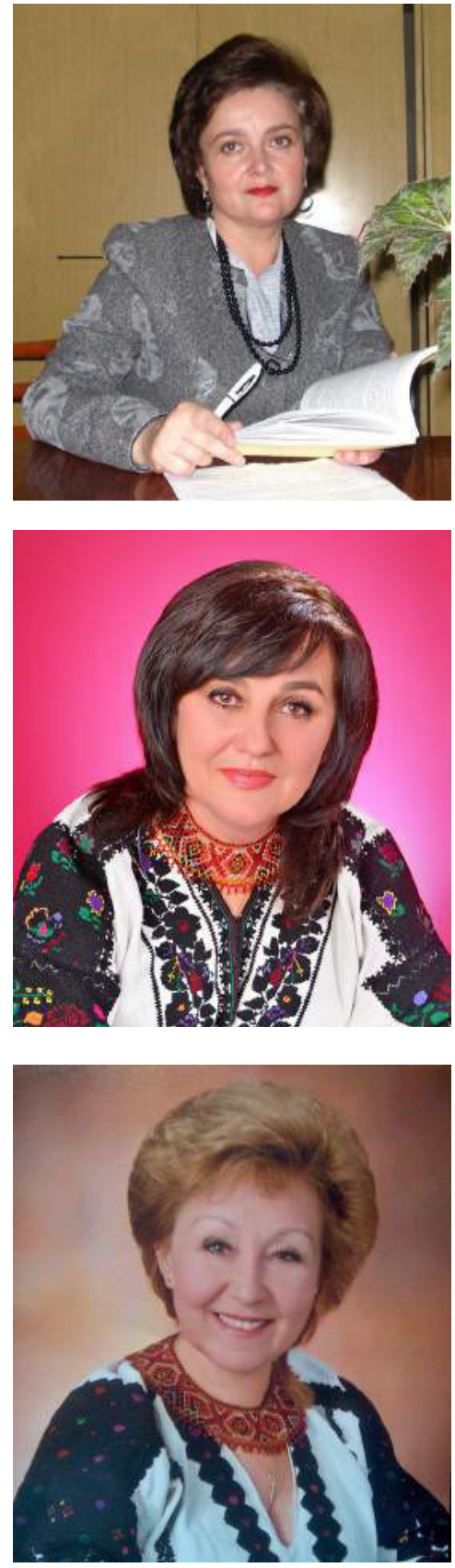

Ірина Липа,

кандидат педагогічних наук, доцент, ДВНЗ «Прикарпатський національний університет імені Василя Стефаника» (м. Івано-Франківськ)

Irena Lypa,

Candidate of Pedagogical Sciences, Associate Professor, Vasyl Stefanyk Precarpathian National University

(Ivano-Frankivsk) iryna.lypa@pu.if.ua

ID orcid.org/0000-0002-1666-2346

\section{Ольга Черсак,}

доцент,

ДВНЗ «Прикарпатський національний університет імені Василя Стефаника» (м. Івано-Франківськ)

\section{Olha Chersak,}

Associate Professor, Vasyl Stefanyk Precarpathian National University

(Ivano-Frankivsk)

olha.chersak@pu.if.ua

ID orcid.org/0000-0003-1619-1334

\section{Ольга Молодій,}

доцент,

ДВНЗ «Прикарпатський національний університет імені Василя Стефаника»

(м. Івано-Франківськ)

\section{Olha Molodiy,}

Associate Professor,

Vasyl Stefanyk Precarpathian National University

(Ivano-Frankivsk)

olha.molodii@pu.if.ua

удк 371

\title{
НАРОДНА ПІСНЯ В КОНТЕКСТІ РЕПЕРТУАРНОЇ ПОЛІТИКИ ДИТЯЧОГО ХОРОВОГО КОЛЕКТИВУ
}

\section{FOLK SONG IN THE CONTEXT OF THE CHILDREN'S CHOIR REPERTOIRE POLICY}

У статті розкривається роль репертуару як найважливішого засобу творчого життя колективу та основи всієї його діяльності. Автори наголошують на характерних особливостях хорового мистецтва, до яких відносять його високодуховну сутність, доступність, невичерпність виховних можливостей, вказують на те що хорове мистецтво не лише сприяє розширенню історико-культурного світогляду зростаючої особистості, задоволенню пізнавальних потреб та інтересів, розвитку інтелектуальних сил, творчих здібностей, але й відкриває перед людиною перспективу нескінченного вдосконалення, емоційно-чуттєвого осягнення національних та загальнолюдських засад духовно-морального буття.

У статті зазначено, що з репертуаром пов'язана не лише ідейно-художня спрямованість мистецтва, але й сам стиль виконавчої майстерності. Відповідно репертуарна політика дитячого хорового колективу впливає на весь навчальновиховний процес, на опанування музично-теоретичних знань та на вироблення вокально-хорових навичок. 
Ключові слова: хоровий спів, репертуар, шкільний хор, українська народна пісня, музичний фольклор, вокальнохорова майстерність.

The article reveals the role of the repertoire as the most important means of creative life of the collective and the basis of all its activities. The authors emphasize the characteristic features of choral art, which include its highly spiritual essence, accessibility, inexhaustibility of educational opportunities, point out that choral art not only contributes to the expansion of the historical and cultural outlook of a growing personality, satisfaction of cognitive needs and interests, the development of intellectual powers, creative abilities, but also opens the prospect of human endless perfection, emotional and sensory comprehension of national and universal principles of spiritual and moral being.

The article states that the repertoire involves not only the ideological and artistic orientation of art, but also the style of performing skills. Accordingly, the repertoire policy of the children's choir affects the entire educational process, the mastering of musical theoretical knowledge and the development of vocal and choral skills.

Keywords: choir singing, repertoire, school choir, Ukrainian folk song, folk music, vocal and choral skills.

В статье раскрывается роль репертуара как важнейшего средства творческой жизни коллектива и основы всей его деятельности. Авторы отмечают характерные особенности хорового искусства, к которым относят его высокодуховную сущность, доступность, неисчерпаемость воспитательных возможностей, указывают на то, что хоровое искусство не только способствует расширению историко-культурного мировоззрения растущей личности, удовлетворению познавательных потребностей и интересов, развития интеллектуальных сил, творческих способностей , но и открывает перед человеком перспективу бесконечного совершенствования, эмоционально-чувственного постижения национальных и общечеловеческих основ духовно-нравственного бытия.

В статье указано, что с репертуаром связана не только идейно-художественная направленность искусства, но и сам стиль исполнительского мастерства. Таким образом, репертуарная политика детского хорового коллектива влияет на весь учебно-воспитательный процесс, на овладение музыкально-теоретическими знаниями и на выработку вокально-хоровых навыков.

Ключевые слова: хоровое пение, репертуар, школьный хор, украинская народная песня, музыкальный фольклор, вокально-хоровое мастерство.

Постановка проблеми в загальному вигляді та її зв'язок з важливими науковими та практичними завданнями. Хорове виконавство є історично традиційним в Україні і займає провідне місце у національній культурі. Донині ця мистецька ділянка стимулює творчість композиторів у створенні високохудожніх зразків, серед яких перебувають і твори, призначені для дитячих колективів. У процесі хорового співу естетичну насолоду отримують і слухачі, і виконавці у тому випадку, коли репертуар складається з різних за змістом і характером, цікавих за тематикою творів високої художньо-естетичної якості, а виконання їх є виразне та емоційне.

Репертуар - найважливіший засіб творчого життя колективу, це його обличчя, його візитка. Проблема репертуару - вагома естетична проблема виконавського мистецтва.

Аналіз останніх досліджень і публікацій, у яких започатковано розв'язання проблеми. Значення репертуару в шкільному хорі величезне і багатогранне. Воно проявляється і у виховній, і в просвітницькій, і в концертно-виконавській діяльності співочого колективу. Ця вагома функція репертуару підкреслюється авторами у багатьох джерелах спеціальної літератури. Так, Л. Шаміна пише: «Репертуар як сукупність творів, виконуваних тим чи іншим хоровим колективом, складає основу всієї його діяльності, сприяє розвиткові творчої активності учасників, знаходиться в безпосередньому зв'язку з різними формами та етапами роботи хору» [6].

П. Халабузар, В. Попов, Н. Добровольська визначають репертуар як «основоположний фактор музичного виховання» [5]. І. Бермес відзначає : «Забезпечення дитячого хорового колективу належним репертуаром, відповідно до його виконавських потенцій, художніх зацікавлень, творчих орієнтирів - завдання непросте і відповідальне. Щоб його успішно реалізувати хормейстеру, крім спеціальної підготовки, треба володіти методикою відбору, перебувати в творчому пошуку» [1]. «Формуючи репертуар для хору тієї чи іншої вікової групи, керівник повинен, перш за все, звертати увагу на відповідність художнього змісту твору можливостям сприймання школярів,а також на такі показники, як перспектива розвитку їхніх музичних смаків і поглядів; підвищення рівня їхнього музичного мислення; удосконалення вокально-хорової техніки і т. д.» - підкреслюють П. Зелінський та Н. Збожимська [2].

Висвітлення проблем про роль української народної пісні в духовному житті підростаючого покоління знайшло відображення й у наукових працях сучасних дослідників, які визначають народні пісні як джерело пам'яті народу, його духовний набуток, дієвий засіб формування національної свідомості суспільства (А. Авдієвський, О. Дей, С. Мишанич, М. Стельмахович, М. Дмитренко та ін.). Науковий доробок зазначених науковців вже вкотре доводить необхідність використання українського фольклору у просвітницькою метою у навчально-виховному процесі та в усіх інших сферах діяльності сучасної загальноосвітньої школи.

Формування мети статті. Метою статті на основі аналізу музично-педагогічної літератури описати репертуарну діяльності дитячого хорового колективу та розкрити актуальні проблеми у художній творчості дитячого хорового колективу.

Виклад основного матеріалу дослідження з повним обґрунтуванням отриманих наукових результатів. Хоровий спів - мистецтво унікальних можливостей, як виконавських, так і освітніх. Він завжди був, $є$ і буде невід'ємною частиною вітчизняної та світової культури, незамінним, століттями перевіреним чинником формування духовно-творчого потенціалу суспільства.

Характерними особливостями хорового мистецтва є його високодуховна сутність, доступність, невичерпність його виховних можливостей. Хорове мистецтво не лише сприяє розширенню історико-культурного світогляду, задоволенню пізнавальних інтересів, розвитку інтелектуальних сил, творчих здібностей, але й відкриває перед людиною перспективу нескінченного удосконалення, прямування до істини, добра, краси, надає їй можливість емоційно-чуттєвого осягнення національних та загальнолюдських основ духовно-морального буття. 
3 репертуаром пов'язана не лише ідейно-художня спрямованість мистецтва, але й сам стиль виконавства. Репертуар впливає на весь навчально-виховний процес, на його основі накопичуються музично-теоретичні знання, виробляються вокально-хорові навички, планується художньо-виконавська діяльність хору. Від умілого підбору творів залежить ріст майстерності колективу, перспективи його розвитку, все, що пов'язане з виконавськими завданнями хорового колективу. Для того, щоб репертуар мав виховний вплив, він завжди повинен бути доступним, відповідати вимогам часу, а головне - відповідати віковим особливостям дітей як за змістом, так і за можливостями подолання вокально-хорових труднощів з урахуванням голосового навантаження та загального діапазону.

Значення репертуару не вичерпується необхідністю показу досягнень колективу. Не менш важливу роль він відіграє в музично-естетичному розвитку його учасників, в підвищенні їх вокально-хорової майстерності, в розвитку музичного смаку виконавців і слухацької аудиторії. «Уміло підібраний, високохудожній репертуар забезпечує творчо активне життя хору, постійно підвищує його виконавську майстерність в цілому і кожного окремого виконавця зокрема. І навпаки, випадково складений репертуар частіше всього призводить до важких наслідків - розпаду хору. Ось чому з такою ретельністю повинна формуватися керівником хору репертуарна політика, особливо в перші часи існування колективу» [5, с. 117].

В. Попов [5] вважає, що для створення творчо активної атмосфери в хорі, в його репертуарі має бути три групи творів: одна повністю відповідати виконавським можливостям колективу, друга - випереджати ці можливості, а третя - бути легшою за досягнутий рівень. Дотримання цього принципу активізує репетиції і допомагає свідомо засвоювати матеріал. Наявність трьох груп складності дозволяє педагогу своєчасно переключати увагу дітей з важкого на легке, змінити ритм у роботі, вчасно зняти напруження. Якщо діти працюють із захопленням, то хормейстеру значно легше впливати на їхню свідомість.

Для кожного вчителя і керівника питання репертуару $є$ першочерговим. Від того, що співається у хорі, значною мірою залежить якість співу. Хормейстер завжди прагне зацікавити хористів тематикою репертуару. Робота над кожною піснею повинна сприяти розвитку умінь та навичок дітей у хоровому співі. До репертуару дитячого хорового колективу слід включати твори різні за характером та жанрами, які вимагають від виконавців умілого використання різних засобів виразності, що впливає на загальну культуру виконання і розвиває їх у художньому відношенні, сприяє набуттю необхідних вокально-хорових навичок.

«Репертуар як сукупність творів, виконуваних тим чи іншим хором, становить основу всієї його діяльності, сприяє підвищенню рівня всього навчально-виховного процесу, накопиченню хористами музично-теоретичних знань і практичних навичок і - врешті решт - допомагає формувати художньо-виконавський напрямок хорового колективу»[3, с. 135]. Від умілого добору творів залежить успіх роботи будь-якого виконавського колективу в усіх його проявах.

До репертуару слід добирати твори різні за характером та жанрами, які вимагають від дітей-виконавців умілого застосування різних засобів виразності, що впливають на загальну культуру виконання, розвивають їх у художньому відношенні, сприяють набуттю необхідних вокально-хорових навичок.

Доступність - відповідність змісту і об'єму набутих знань віковим особливостям учнів, а також існуючим у них знанням і уявленням - один із дидактичних принципів. Під час добору репертуару керівник хору повинен враховувати як технічну доступність або спроможність виконання музичного твору конкретним хоровим колективом, так і доступність сприйняття аудиторією, перед якою цей твір буде виконуватись. Розглядаючи хорові партитури і аналізуючи їх щодо вокально-хорової техніки виконання, бажано добирати твори трьох рівнів складності, як це пропонує В.Попов. У процесі вивчення творів важливо, щоб хористи не перевтомлювалися від нездоланно складних хорових полотен, що, в свою чергу, психологічно негативно позначиться на самому бажанні співати. Межу складності повинен відчувати керівник хору, орієнтуючись і на сприйняття аудиторії. Не можна перевантажувати слухача сучасною модерновою музикою, яка ще незвична, а іноді не всім зрозуміла за засобами виразності і викладом, але знайомити у невеликій кількості все ж таки бажано.

Однією з найважливіших частин репертуарних програм шкільних хорів є народна пісня. Яскрава мелодійність, ритмічна гнучкість, вокальна зручність, багатство інтонаційних та динамічних відтінків - всі ці якості роблять народну пісню незамінним матеріалом для хорового співу в школі. Пропаганда народних пісень як в оригінальному, так і в обробленому вигляді має принципове значення для творчої роботи шкільних хорів, оскільки пісенний фольклор найбільш близький і зрозумілий широкому колу виконавців і слухачів. Українська народна пісня $€$ одним із найпопулярніших жанрів музичного мистецтва. Вона є скарбницею людської духовності, що полонить почуття, розум і серце. В українській пісні відтворюється світогляд народу, його морально-етичні та естетичні цінності, багатовіковий досвід виховання підростаючих поколінь у дусі високої духовності та моралі. Тому, на нашу думку, українська народна пісня має стати основою музичного матеріалу, що використовується в репертуарі дитячого хорового колективу.

Народна пісня як засіб естетичного виховання, починаючи зі шкільного етапу, широко репрезентується у спадщині видатних педагогів та діячів освіти. Українські композитори-класики завжди вважали народну пісню найдовершенішим засобом суспільного і художнього виховання, тому чимало збірок, що містять обробки українських народних пісень, вони присвятили дітям. Виховна сила народних пісень зумовлена передусім тим, що своїм змістом, мелодією спрямована на формування почуттів людини. М. Лисенко закладає основи естетичного виховання молоді. В основу своїх посібників для школи композитор поклав кращі зразки української пісні. Збірник М. Лисенка «Молодощі», виданий у 1875 р., є першим значним зібранням українських ігрових пісень і веснянок. Дуже корисною і популярною була збірка К. Стеценка «Луна», розрахована на школярів і домашнє музикування дітей. За основу шкільного хорового матеріалу композитор узяв народну пісню. Загалом ця збірка характеризується вдалим добором матеріалу та майстерним його опрацюванням. Другою значною музичною працею К. Стеценка був «Шкільний співанник» - енциклопедія народного життя та побуту, відтворена у вигляді досконалих за художньою формою і різних за жанром пісень: «Ой дзвони дзвонять», «Калач», «Зайчик», «Добрий вечір тобі» тощо. 
У 20-ті роки XX ст. з'явилося чимало спеціальних збірників: три випуски «Пролісків» Я. Степового, «Дитяча розвага» С. Титаренка, «Гра» (упорядник Р. Вовк), «Дитячі пісні» М. Вериківського, «Весняночка» В. Верховинця, «Слобожанські народні пісні для школи» В.Ступницького.

Естетичні аспекти притаманні й педагогічній спадщині Ф. Колесси. Палкий шанувальник рідної пісні М. Леонтович послідовно дотримувався визначальної їі ролі у справі музично-естетичного виховання дітей. Він вважав, що завдяки виконанню народних пісень в учнів виховуються естетичні почуття, художній смак, зміцнюється музична слухова пам'ять.

Дитячі народні пісні не лише розважають, а й збагачують дітей новими враженнями, дають їм яскраві образи навколишньої природи, вчать радіти щастю інших, співчувати чужому горю, виховують чуйне ставлення до всього живого і таким чином збагачують духовний світ дитини. «Гарна лірична пісня, побудована на народних інтонаціях, сюжетне полотно, що розкриває історичне минуле народу, жартівлива пісня, наповнена здоровим народним гумором, - все це може послужити цікавим матеріалом для виховної роботи в колективі» - підкреслює Л. Шаміна [ 6, 134].

Психологічно-виховний вплив народної пісні на людину $€$ безперервним багатогранним процесом. За її активною допомогою не тільки формується, а й підтримується народна система дидактичних знань. Таким чином, навіть у дітей з родин, де не дуже добре дбали про виховання, завдяки фольклору.

Великим надбанням, неоціненним скарбом кожного народу є його музична культура, і якщо немає народу без мови, то такою ж мірою можна стверджувати, що немає його і без національної музики, без народної пісні. Секрет майстерності народних пісень у тому, що в них переважають загальнолюдські почуття та переживання. Пісні несуть у собі високу народну мораль, поетизують працьовитість, добро, щирість, почуття. Підкреслюючи значення фольклору в становленні особистості, В. О. Сухомлиський писав: «Мелодія і слово рідної пісні - це могутня виховна сила, яка розкриває перед дитиною народні ідеали і надії» [4, 187].

Доля багатьох пісень подібна до долі нашого народу. Коли народ оживав, воскресав - оживали, воскресали і його пісні. Коли його гнітила неволя, духовне рабство, то замовкала і пісня - народна душа. Замовкала, але ніколи не вмирала. Багато пісень загубилось на тернистих шляхах нашого народу, та настав час відшукати загублені колиски народної мудрості, розбудити знову до життя, щоб вони виховували в наших школярів кращі моральні якості, щоб діти чули їх і співали в школі та вдома, ставали від них добрішими, щирішими, працьовитішими, гідними нащадками своїх славних предків. Щоб відчути красу та ніжність української народної пісні, скористатись її порадою і допомогою, необхідно проникнутись нею всім серцем, всією душею, долучитись до неї на уроках музики, в дитячих хорових колективах, вокальних групах, фольклорних ансамблях. Навіть ті пісні, які дітям доводилось чути раніше, тепер для них зазвучать по-новому. Вони усвідомлять зміст твору, мимоволі стануть свідками подій, явищ чи сцен, про які співають. Основним завданням виховання учнів засобами народної пісні $\epsilon$ перехід від переважно емоційного сприймання і відтворення ними краси образу твору до рівня його осмислення, пізнання глибинної сутності. Тому, на нашу думку, українська народна пісня має стати основою музичного матеріалу, що використовується в хоровій практиці шкільних колективів. Задля ефективного проведення музичноестетичної роботи з учнями на заняттях хорового колективу вчитель повинен взяти за основу музичний фольклор, який є основним засобом впливу на духовний світ школярів, на сферу їх емоцій і почуттів.

Шлях до успіху кожного хормейстера - справа творча, яка вимагає не тільки бажання і високих професійних якостей, виняткових здібностей і відповідних музично-теоретичних знань, а й наполегливості, послідовності, кропіткої праці, адже керування дитячим колективом $€$ надзвичайно відповідальною і почесною місією, яка вимагає від людини повної присвяти себе цій діяльності.

Висновки і перспективи подальших досліджень. Невичерпність духовних цінностей народної пісні, новаторство українських композиторів у галузі хорової обробки народних пісень і створені ними високохудожні обробки піднесли жанр на небувалу височінь. Цей національний мистецький скарб, без сумніву, заслуговує на увагу педагогів і підлягає детальному вивченню і використанню в репертуарі дитячих хорових колективів. Відродження України, її духовності неможливе без рідної пісні, яка жила вічно з нашим багатостраждальним народом і дійшла до нас як найдорогоцінніший скарб, що підтримував українця упродовж усього його життя та передавався у спадок з покоління в покоління. Перспективи подальших наукових розвідок пов'язуємо із дослідженням змістового наповнення шкільного репертуару хорових колективів.

1. Бермес І. Репертуар дитячого хору як педагогічна проблема / І. Бермес. - Молодь і ринок. - 2015. - №9 (128). - С. 16.

2. Зелінський П., Збожимська Н. Репертуар шкільного хору як фактор музично-естетичного виховання учнів / П. Зелінський, Н. Збожимська// Проблеми підготовки сучасного вчителя: Збірник наукових праць. - Умань: ПП Жовтий О., 2012. - № 6. 4.2. - С $209-215$.

3. Мархлевський А. Ц. Практичні основи роботи в хоровому класі. - К : Музична Україна, 1986. - С. 135 - 137.

4. Сухомлинський В. О. Вибрані твори: у 5 т. / - К., 1997. - Т. 3. - 670 с.

5. Халабузар П. Методика музыкального воспитания / П. Халабузар, В. Попов, Н. Добровольская. - М.: Музыка, 1990.

6. Шамина Л. Работа с детским хоровым колективом / Л. Шамина. - М.: Музыка, 1988. - 176 с.

\section{Reference}

1. Bermes I. Repertuar dytiachogo khoru yak pedagogichna problema / I. Bermes. - Molod` i rynok. - 2015. - №9 (128). - S. 16.

2. Zelins'kyj P., Zbozhyms`ka N. Repertuar shkil'nogo khoru yak faktor muzychno-estetychnogo vykhovannya uchniv / P. Zelins`kyj, N. Zbozhyms`ka// Problemy pidgotovky suchasnogo vchytelya: Zbirnyk naukovykh pracz`. - Uman`: PP Zhovtyj O., 2012. - №6. ch.2. $-\mathrm{S} 209-215$.

3. Markhlevs`kyj A. Cz. Praktychni osnovy roboty v khorovomu klasi. - K : Muzychna Ukrayina, 1986. - S. $135-137$.

4. Sukhomlyns 'kyj V. O. Vybrani tvory: u 5 t. / K., 1997. - T. 3. - 670 s.

5. Khalabuzar P. Metodika muzykal'nogo vospitaniya / P. Khalabuzar, V. Popov, N. Dobrovol’skaya. - M.: Muzika, 1990.

6. Shamina L. Rabota s detskim khorovym kolektivom / L. Shamina. - M.: Muzyka, 1988. - 176 s. 